\title{
Luottamusta ja harkintaa. Kuluttajien näkökulmia ruoan turvallisuuteen ja elintarvikeketjuun.
}

\author{
Sanna Piiroinen ${ }^{1}$, Mari Niva ${ }^{1}$ ja Johanna Mäkelä ${ }^{1}$ \\ ${ }^{1}$ Kuluttajatutkimuskeskus, PL 5, 00531 Helsinki, etunimi.sukunimi@ncrc.fi
}

Luottamuksesta ruokaan ja etenkin sen puutteesta on keskusteltu vilkkaasti viime vuosina, kun erilaiset ruokakriisit ovat ravistelleet Eurooppaa. Myös funktionaaliset elintarvikkeet, geenimuunneltu ruoka ja ruoan terveellisyys sekä niihin liittyvä moninainen informaatio kiinnostavat ja toisaalta huolestuttavat kuluttajia. Kuluttajien luottamus ruokaan ja koko elintarvikeketjun toimintaan on ajankohtainen teema niin meillä kuin muualla Euroopassakin.

Tämä esitys perustuu tutkimukseen, jossa tarkasteltiin kuluttajien luottamusta eri elintarvikkeiden turvallisuuteen sekä elintarvikeketjun toimijoihin. Tutkimuksen taustalla on vuosina 2002 2004 toteutettu EU:n rahoittama hanke 'Consumer trust in food. A European study of the social and institutional conditions for the production of trust'. Eurooppalainen tutkimus tarkasteli ruokaan liittyvää luottamusta kuudessa maassa; Isossa-Britanniassa, Italiassa, Norjassa, Portugalissa, Saksassa ja Tanskassa. Suomessa kerättiin vastaava kvantitatiivinen aineisto kuin tutkimukseen osallistuneissa maissa. Suomea vertailtiin soveltuvin osin EU-tutkimuksessa mukana olleisiin maihin.

Tutkimukseen osallistui 1207 iältään 18-79-vuotiasta kuluttajaa eri puolilta Suomea. Aineisto kerättiin kesällä 2003 puhelinhaastatteluilla. Tutkimuksessa tarkasteltiin luottamuksen erilaisia osatekijöitä. Kohteina olivat luottamus ruokaan yleensä, luottamus eri tavoin tuotettuja, käsiteltyjä ja erilaisista raaka-aineista peräisin olevia ruokia ja elintarvikkeita kohtaan sekä luottamus institutionaalisiin toimijoihin. Lisäksi analysoitiin vastaajien näkemyksiä elintarvikeketjun eri osapuolten vastuusta ja vastuullisuudesta ruokaan liittyvissä kysymyksissä.

Tulosten perusteella suomalaiset kuluttajat luottavat suhteellisen voimakkaasti ruoan turvallisuuteen ja elintarvikeketjun toimintaan verrattuna muihin eurooppalaisiin. Eri elintarvikkeisiin ja toimijoihin kuitenkin luotetaan eri tavoin ja niiden luotettavuus punnitaan jatkuvasti arkipäivän tilanteissa. Miehet luottavat ruoan turvallisuuteen naisia enemmän, mutta muutoin sosiodemografiset taustamuuttujat erottelevat kuluttajia heikosti. Luottamuksen eri osatekijät ovat yhteydessä toisiinsa. $\mathrm{Ne}$, jotka luottavat vahvasti ruokaan yleensä, luottavat muita enemmän myös erilaisten yksittäisten elintarvikkeiden turvallisuuteen, elintarvikeketjuun ja muihin ihmisiin.

Asiasanat: luottamus, kuluttajat, elintarvikkeet, ruoka, ruoan turvallisuus 


\section{Johdanto}

Kysymys siitä, luotetaanko ruokaan, kohdataan monella tapaa. Onko ostamani valmisruoka varmasti syömäkelpoista, vaikka viimeinen myyntipäivä lähestyy? Onko geenimuunnettu ruoka vaarallista ympäristölle ja terveydelle? Onko luomutuote ympäristöystävällisempi kuin tavanomaisesti tuotettu? Miten eläinten rehuihin voi päästä ihmisille vaarallisia myrkkyjä? Luottamus tai epäluottamus voivat kohdistua niin yksittäisiin tuotteisiin kuin ruoan tuottajiin, valvojiin tai tutkijoihin. Luottamuksen puute voi merkitä huolta terveys- tai ympäristöhaitoista, mutta yhä useammin myös ruoantuotannon sosiaalisista seurauksista. Keskustelu ruoan turvallisuudesta liittyy ruokajärjestelmämme monimutkaistumiseen. Ruoan tie alkutuotannosta lopputuotteeksi on pidempi kuin ennen. Matkalla raakaaineesta valmiiksi tuotteeksi kuluttajan jääkaappiin on lukuisia toimijoita ja vaiheita, joiden rooli ja merkitys ruoan turvallisuudessa välittyvät vain heikosti loppukäyttäjille asti.

Luottamuksesta ruokaan ja sen puutteesta on viime vuosina puhuttu vilkkaasti, kun erilaiset ruokakriisit ovat ravistelleet Eurooppaa. Luottamus on noussut keskiöön niin markkinatoimijoiden kuin poliitikkojen ja viranomaisten käsitteistössä puhuttaessa ruoantuotannon ongelmista ja turvallisuudesta. EU:n komission elintarvikkeiden turvallisuutta käsittelevässä valkoisessa kirjassa nähdään kuluttajien luottamus tärkeänä elintarvikepolitiikan tavoitteena. Myös Suomessa elintarviketurvallisuus on tärkeä kysymys. On laadittu uutta lainsäädäntöä, toimintaohjelmia ja strategioita kuluttajien luottamuksen vahvistamiseksi ja ylläpitämiseksi. Kuluttajalähtöisyys korostuu kansallisen elintarviketalouden laatustrategian ja -työn perusteissa, joissa kuluttajan tarpeiden ja odotusten katsotaan ohjaavan koko elintarvikeketjun toimintaa.

Luottamus on aihe, jota on käsitelty paljon yhteiskuntatieteellisessä tutkimuksessa myös Suomessa (ks. esim. Misztal 1996, Ilmonen ja Jokinen 2002). Tutkimus on ollut pitkälti teoreettista ja analysoinut luottamusta yhteiskuntia ja yhteisöjä koossapitävänä voimana esim. sosiaalisen pääoman käsitteen kautta (ks. esim. Ilmonen 2000). Sen sijaan voimistuvasta julkisesta keskustelusta huolimatta laaja-alaista empiiristä tutkimusta siitä, missä määrin ruokakriisit ovat mahdollisesti rapauttaneet kuluttajien luottamusta ruokaan ja sen tuotantoon ja mihin mahdollinen epäluottamus kohdistuu, on tehty vasta vähän (ks. kuitenkin Gronow 1998, Berg 2000, Berg ja Kjærnes 2001). Suomessa on perinteisesti luotettu viranomaisten ja muiden ruoan turvallisuuden kanssa tekemisissä olevien instituutioiden toimintaan. Jukka Gronowin (1998) mukaan tämä on osaltaan vaikuttanut siihen, ettei Suomessa ole mahdollisten ongelmien yhteydessä syntynyt hysteriaa. Gronow korostaa, ettei voimakkaiden kansalaisreaktioiden puuttumisesta voida suoraan tehdä johtopäätöstä, että Suomessa ruoka olisi sen turvallisempaa kuin muuallakaan. Sen sijaan vallitseva luottamus merkitsee, ettei ruokaskandaaleilla ole Suomessa kovin otollista maaperää aiheuttaa paniikkireaktioita. Yhteiskunnan kannalta riskien ja vaarojen sietokyky liittyy sosiaalisten instituutioiden nauttimaan luottamukseen. Jos se ei ole uhattuna, eivät ruokaan liittyvät pelot ja uhat voi saavuttaa hälyttäviä mittasuhteita.

Luottamuksen näkökulmasta tärkeä eurooppalainen hanke on vuonna 2002 alkanut Consumer Trust in Food. A European Study of the Social and Institutional Conditions for the Production of Trust (ks. http://www.trustinfood.org/). Se tarkasteli ruokaan kohdistuvan luottamuksen ehtoja ja edellytyksiä kuudessa Euroopan maassa; Isossa-Britanniassa, Italiassa, Norjassa, Portugalissa, Saksassa ja Tanskassa. Hanke koostui kahdesta osiosta. Ensimmäisessä osiossa kerättiin kvantitatiivinen, väestöä edustava kyselyaineisto, jonka avulla selvitettiin kansalaisten luottamusta ruokaan. Toisessa vaiheessa tarkasteltiin kahden laadullisen tapaustutkimuksen kautta ruoantuotantoon liittyviä strategioita. Olennainen osa tutkimusotetta oli kansainvälinen vertailu, sillä osiot toteutettiin samanlaisina kaikissa maissa. Suomi ei ollut mukana EU:n rahoittamassa hankkeessa varsinaisena kumppanina. Kuluttajatutkimuskeskus kuitenkin osallistui ensimmäiseen, kvantitatiiviseen osioon eräänlaisena satelliittina (ks. Piiroinen ym. 2004). Suomalaista tutkimusta rahoittivat Elintarvikkeiden Tutkimussäätiö ja Kuluttajatutkimuskeskus. 


\section{Aineisto ja menetelmät}

Suomessa kerättiin kesällä 2003 yhteistutkimuksen kyselylomaketta käyttäen vastaava aineisto kuin tutkimukseen osallistuneissa kuudessa maassa. Tutkimusaineiston $(\mathrm{N}=1207)$ keräsi TNS Gallup Oy tietokoneavusteisina puhelinhaastatteluina. Tutkimusaineisto kiintiöitiin keruuvaiheessa väestöä edustavaksi sukupuolen, asuinpaikan ja iän mukaan. Vastaajat olivat iältään 18-79-vuotiaita.

Kyselyyn sisältyi neljä aihealuetta. Kyselyn alussa oli kysymyksiä koskien ruoan ostoa ja ruokatottumuksia sekä kuluttajan ja kansalaisen rooleja. Toinen aihepiiri käsitteli ruokaan liittyvän vastuun jakautumista elintarvikeketjun ja yhteiskunnan eri toimijoiden sekä kuluttajien kesken. Vastuukysymysten jälkeen siirryttiin varsinaiseen luottamusta käsittelevään osuuteen. Tarkastelun kohteena olivat $\mathrm{mm}$. luottamus yksittäisiin ruokiin ja elintarvikkeisiin, luottamus elintarvikeketjun toiminnan ja ruoan laadun kehitykseen pitkällä aikavälillä sekä luottamus eri instituutioiden toimintaan tiedon välittäjinä. Viimeisen aihealueen muodostivat taustakysymykset.

Aineisto analysoitiin SPSS for Windows -ohjelmiston versiolla 11.5. Aineiston pääasiallisina kuvailu- ja analyysimenetelminä käytettiin suoria jakaumia sekä ristiintaulukointia ja tulosten tilastollisen merkitsevyyden tarkasteluun $\chi^{2}$-testiä. Ristiintaulukointi soveltuu hyvin luokitteleville muuttujille, jotka tässä tutkimuksessa usein olivat kolmiluokkaisia. Tämän lisäksi alkuperäisiä muuttujia yhdistettiin muiden tutkimuksessa mukana olleiden maiden esimerkin mukaan keskiarvomuuttujiksi, indekseiksi, joita käytettiin erityisesti vertailtaessa Suomea muihin maihin.

\section{Tulokset ja tulosten tarkastelu}

\section{Luottamus ruoan turvallisuuteen}

Yli puolet vastaajista (59 \%) ilmoitti luottavansa ruoan turvallisuuteen suuressa määrin ja lähes kaikki muut vastaajat (40 \%) jossakin määrin. Ainoastaan yksi prosentti vastaajista luotti ostamansa ruoan turvallisuuteen hyvin vähän. Naisista (55\%) hieman harvempi kuin miehistä (63\%) ilmoitti luottavansa ostamansa ruoan turvallisuuteen suuressa määrin, ja naisten hieman miehiä vähäisempi luottamus ilmeni vielä selvemmin, kun tarkasteltiin luottamusta yksittäisten ruokien ja elintarvikkeiden turvallisuuteen. Luottamus ruokaan ja tätä kautta myös elintarvikemarkkinoihin näyttäisi olevan melko voimakasta tai ainakin kohtuullista, sillä tämän muuttujan perusteella ei Suomesta löydy vastaajien joukosta selkeästi epäluottavaisten ryhmää. Kuitenkin neljä kymmenestä vastaajasta luottaa ruoan turvallisuuteen vain osittain, mikä kertoo siitä, että ruoan turvallisuuteen liittyy epävarmuustekijöitä. Nämä epävarmuustekijät saattavat olla yhteydessä yleiseen epätietoisuuteen tai lievään epäilyyn ruoan turvallisuudesta tai markkinoiden ja instituutioiden toiminnasta, tai ne voivat kohdistua tiettyihin tuotteisiin tai tuoteryhmiin (esim. valmiiksi pakattuihin lihoihin tai lihaan yleensä).

Ruoan turvallisuuteen liittyen vastaajille esitettiin 16 eri ruokaa tai elintarviketta, joiden turvallisuutta heidän tuli arvioida. Ruokien joukko oli hyvin moninainen. Joukossa oli käsittelyä vaativia raaka-aineita (esim. naudanliha, kananmunat), jalostettuja elintarvikkeita (esim. makkara, säilyketomaatit) sekä ruoka-annoksia (ravintolaruoka, hampurilaiset). Tuotekohtaisessa tarkastelussa ilmeni hyvin se, että kaikki vastaajat eivät luota ruoan turvallisuuteen yhtä voimakkaasti ja että kaikkia ruokia tai elintarvikkeita ei koeta yhtä turvallisiksi (kuvio 1). Silti suurinta osaa ruoista pidettiin ainakin melko turvallisina. Kaikista turvallisimpina pidettiin tuoreita tomaatteja ja tuoreita hedelmiä ja kasviksia yleensä, joita piti erittäin turvallisena noin kolme neljästä vastaajasta. Ainoastaan geenimuunnettu tomaatti poikkesi muista selvästi siten, että sen turvallisuuden arvioi heikoksi yli puolet vastaajista. Arvioissa näkyy se, miten samasta raaka-aineesta peräisin olevia elintarvikkeita voidaan pitää turvallisuudeltaan hyvin erilaisina. 


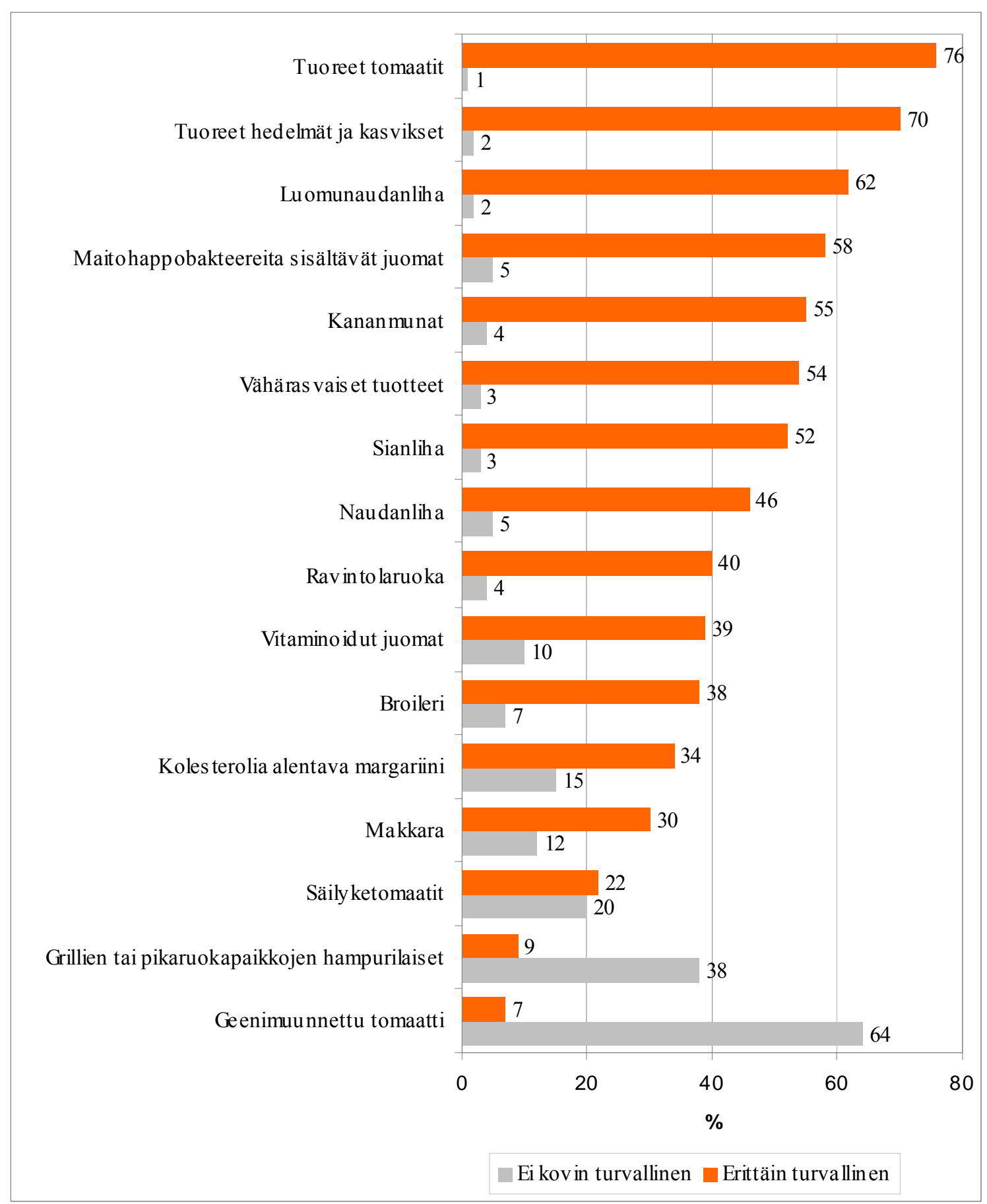

Kuvio 1. Vastaajien näkemykset tiettyjen ruokien ja elintarvikkeiden turvallisuudesta $(\%, N=1207)$.

Yksittäisten elintarvikkeiden lisäksi vastaajia pyydettiin arvioimaan erilaisten ruokaan ja sen laatuun vaikuttavien tekijöiden kehitystä pidemmällä aikavälillä. Kysymys kuului: Ovatko seuraavat elintarvikkeisiin ja ruokaan liittyvät asiat mielestänne parantuneet, pysyneet suunnilleen ennallaan vai huonontuneet viimeisen kahdenkymmenen vuoden aikana?. Arvioinnin kohteina olivat ruoan maku ja laatu, hinta, turvallisuus, terveellisyys ja ravintosisältö sekä maatalouden tuotantomenetelmät. Ruoan turvallisuutta, terveellisyyttä ja ravintosisältöä sekä maatalouden tuotantomenetelmiä pidettiin tänä päivänä parempina kuin aikaisemmin. Luottamukseen kiinteästi liittyvän ruoan turvallisuuden näki parantuneen $71 \%$ vastaajasta ja $9 \%$ oli sitä mieltä, että turvallisuus oli heikentynyt. Ruoan maun ja laadunkin näki parantuneen useampi kuin neljä kymmenestä (45\%) vastaajasta ja suunnilleen yhtä moni (42\%) oli sitä mieltä, että ruoan laatu ja maku ovat pysyneet kutakuinkin ennallaan. Korkea 
luottamus voi ainakin osin perustua siihen, että ruoan turvallisuuden ja laadun eteen nähdään tehdyn töitä.

Usko ruoan turvallisuuteen ei kuitenkaan ole aukotonta. Kuluttajat olivat myös huolissaan ruoan turvallisuuteen ja laatuun liittyvistä tekijöitä. Vaikka edellä nähtiin, että kuluttajat kokevat ruoan kehityksen menneen monelta osin parempaan suuntaan, se ei kuitenkaan tarkoita sitä, etteikö kuluttajien mielestä ruoan tuotantoon, tarjontaan ja kulutukseen liittyisi nykyisin huomattaviakin ongelmia. Ruoka voi olla turvallista, mutta sitä samalla uhkaavat monet tekijät. Suurimpina ruokaan liittyvinä, koko yhteiskuntaa koskettavina ongelmina pidettiin epäterveellisiä ruokatottumuksia (75\%) ja allergioita (69\%). Useampi kuin puolet vastaajista piti ongelmana myös hullunlehmäntautia, geenitekniikalla muunneltuja elintarvikkeita, torjunta-aineiden käyttöä, ruokamyrkytyksiä, lisäaineita ja eläinten hyvinvointia.

\section{Luottamus ongelmatilanteessa}

Luottamus on kontekstisidonnaista eli se ei pysy muuttumattomana tilanteesta toiseen, vaan vaihtelee olosuhteiden, tapahtumien ja kokijan mukaan. Sen luonteeseen kuuluu, että se on huomattavasti helpompi menettää kuin saavuttaa uudelleen. Entä jos kuluttajien luottamus joutuisikin koetukselle todellisessa ongelmatilanteessa? Ongelmatilanteeksi vastaajille esitettiin mahdollinen broilerintuotannossa esiin tuleva ruokaskandaali ja heitä pyydettiin arvioimaan, kuinka rehellisesti uskoisivat eri tahojen tiedottavan asiasta. Kuluttajajärjestöjä pidettiin luotettavimpina tiedon välittäjänä, kolme neljästä (74 \%) vastaajasta uskoi niiden kertovan koko totuuden mahdollisesta ongelmasta ja ainoastaan kaksi prosenttia uskoi tämän tahon salaavan tietoa Seuraavaksi luotettavimmiksi koettiin (tarkemmin määrittelemättömät) elintarvikealan asiantuntijat (64\%) ja sen jälkeen viranomaiset (55\%). Myös media nähtiin melko luotettavana, puolet (52\%) vastaajista oli sitä mieltä, että media kertoisi skandaalista koko totuuden ja vain neljä prosenttia vastaajista ajatteli median salaavan tietoa.

Edellisiä epäluotettavammiksi koettiin markkinatoimijat, jotka toimivat elintarvikkeiden tuotantoketjussa alkutuotannosta kauppaan. Vastausten jakaumat olivat niin maataloustuottajilla, elintarviketeollisuudella kuin kauppaketjuillakin hyvin samansuuntaiset. Niiden uskoi kertovan koko totuuden 23-29\% vastaajista ja noin $15 \%$ arvioi niiden salaavan tietoa. Markkinatoimijat, joiden tulos ja jopa toimeentulo vaarantuvat esitetyssä skandaalitapauksessa, nähtiin epäluotettavampina kuin sellaiset toimijat, joilla varsinaista omaa etua - ainakaan taloudellista - ei ole. Viranomaisten valvonnan pettäessä niidenkin maine ja tätä kautta luottamus ovat uhattuina, mutta kuluttajien luottamusta toimijoiden rehellisyyteen näyttää heikentävän se, että toimijalla on omat taloudelliset intressit uhattuna. Kaikkein epäluotettavimmaksi, selvästi muista erottuen, koettiin poliitikot. Ainoastaan $13 \%$ vastaajista uskoi poliitikkojen kertovan mahdollisesta ruokaskandaalista kaiken, kun taas $30 \%$ arvioi näiden salailevan ja lähes kuusi kymmenestä piti osatotuuden kertomista todennäköisimpänä vaihtoehtona.

\section{Suomi ja muut maat}

Suomen tulosten vertailu muissa maissa saatuihin tuloksiin ei ollut aivan yksinkertaista. Vertailua hankaloitti se, että muiden maiden aineistot on yhdistetty analyyseja varten, joten yksittäisen, analyysien ulkopuolisen maan tulokset eivät ole suoraan vertailukelpoisia näin saatuihin tuloksiin. Erilaisista aineistoista ja analyysimenetelmistä huolimatta on kiinnostavaa tarkastella Suomen tuloksia muualla saatujen tulosten valossa. Joitakin Suomea koskevia tuloksia (suoria jakaumia) voidaan myös suoraan verrata muiden maiden vastaaviin, mutta osaa niistä täytyy kuitenkin tarkastella ilman varsinaista vertailua.

Ennakko-oletuksemme oli, että tutkimuksessa mukana olleista maista Suomi muistuttaisi eniten muita Pohjoismaita. Pohjoismaissa yleistä on melko voimakas luottamus niin muihin ihmisiin kuin instituutioihinkin. Myös kulttuurinen ja sosiaalinen ympäristö ovat maissa hyvin samanlaisia. Moniin muihin maihin verrattuna Pohjoismaissa markkinat ovat pienemmät ja ruokakriisejä on ollut suhteellisen vähän.

Suuressa määrin ostamansa ruoan turvallisuuteen luottavien osuudet maittain vaihtelivat välillä 8-57\%, joten maiden voi sanoa poikkeavan toisistaan huomattavasti luottamuksessa turvallisuuteen (Poppe ja Kjærnes 2003). Luottavaisimpia kuluttajat olivat Norjassa ja Britanniassa ja epäluottavaisimpia Italiassa ja Portugalissa. Tarkasteltaessa näkemyksiä yksittäisten elintarvikkeiden turvallisuudesta maitten välillä oli myös selkeitä eroja. Suomessa lähes kaikki elintarvikkeet arvioitiin 
turvallisemmiksi kuin muissa maissa keskimäärin. Suomessa pidettiin erittäin turvallisena kaikkia muita maita useammin luomunaudanlihaa, sianlihaa, vähärasvaisia tuotteita sekä ravintolaruokaa. Verrattuna yksittäisiin maihin Suomi muistuttaa hyvin paljon Isoa-Britanniaa, missä useita tuotteita pidettiin turvallisempina kuin muissa maissa. Kaikissa maissa tuoreet vihannekset/hedelmät ja tomaatit arvioitiin turvallisimmiksi. Kaikkia maita yhdisti myös se, että hampurilaisia pidettiin vähiten turvallisina.

Luottamus vaihtelee niin Suomessa kuin muuallakin melko paljon sen mukaan, minkälaisista ruoista on kyse. Tulosten perusteella näyttää siltä, että Iso-Britannia, Norja ja Tanska ovat lähinnä Suomen tilannetta, jota kuvaa vähintäänkin kohtuullinen luottamus ruoan turvallisuuteen. Demografiset tai esimerkiksi ruokatapoihin liittyvät muuttujat eivät näytä vaikuttavan luottamukseen tutkituissa maissa, poikkeuksena sukupuoli. Naiset suhtautuvat lähes kaikkialla ruoan turvallisuuteen epäilevämmin kuin miehet. Pohjoismaat, etenkin Suomi ja Norja, sekä Iso-Britannia ovat melko korkean luottamuksen maita, kun taas Italiassa ja Portugalissa luottamus ruokaan on vähäistä. Saksa asettuu näiden kahden ääripään välimaastoon. (Poppe ja Kjærnes 2003).

Suomen tulosten vertaaminen muihin maihin antaa aihetta pohtia, mistä kuluttajien korkea luottamus Suomessa johtuu. Suomessa on perinteisesti luotettu asioiden toimivuuteen sekä muiden ihmisten rehellisyyteen, eikä luottamus ole joutunut peruuttamattomasti koetukselle. Muissa Pohjoismaissa yhteiskuntarakenne on Suomen kaltainen, ja tutkimuksen tulokset osoittavat, että myös luottamuksessa maat muistuttavat melko paljon toisiaan.

\section{Johtopäätökset}

Jotta olisi mahdollista saada laajempaa ymmärrystä luottamuksen muotoutumisesta, on hyvä tarkastella minkälaisia ulottuvuuksia erilaisiin ruokiin ja elintarvikkeisiin liittyy. Luottamus näyttäisi ensinnäkin liittyvän ainakin osin siihen, kuinka työstetty tai työstämätön jokin elintarvike on. Grillien ja pikaruokapaikkojen hampurilaisia voidaan pitää hyvinkin työstettyinä tuotteina ja niiden turvallisuuteen suhtaudutaankin kriittisesti. Kuluttajien on vaikea selvittää monista eri osista muodostuvan hampurilaisen kaikkia vaiheita raaka-aineista valmiiksi ruoaksi. Turvallisimmiksi elintarvikkeiksi koettiin tuoreet tomaatit, hedelmät ja muut kasvikset, jotka voidaan mieltää käsittelemättömiksi ja "luonnollisiksi" (vrt. Niva ym. 2005). Niihin ei liitetä turvallisuutta uhkaavia riskejä, vaikka lehdistä saa usein lukea esimerkiksi Tullilaboratorion tutkimuksista koskien tuoreiden vihannesten mahdollisia torjunta-ainejäämiä. Aikaisemmat tutkimukset ovat osoittaneet, että lisäaineet ym. kemialliset riskit askarruttavat kuluttajia enemmän kuin mikrobiologiset riskit, joihin kuluttajat periaatteessa voivat omalla toiminnallaan vaikuttaa (Miles ym. 2004, Järvelä 1998a). Tämä ei kuitenkaan käy ilmi, kun kuluttajat arvioivat tuoreiden kasvisten tai hedelmien turvallisuutta. Silloin arvioihin ilmeisesti vaikuttaa jonkinlainen "luonnollisuuden" ulottuvuus, mutta ehkä myös tuttuus, terveellisyys ja jopa kotimaisuus.

Turvallisuuden luonnetta ja merkitystä on syytä pohtia. Turvaton voi ruoan yhteydessä merkitä sitä, että jokin tuote on "vaarallinen" minulle, mutta turvallisuuteen liittyy muitakin ulottuvuuksia. Tuote voi aiheuttaa riskin esimerkiksi jollekin erityisryhmälle (esim. keskustelu kalansyönnin rajoituksista raskaana oleville ja lapsille). Turvallisuuden kääntöpuoli, käytettäköön siitä nyt nimitystä terveysvaara, voi olla lyhyen, mutta myös pitkän aikavälin ongelma. Ruokamyrkytys tai äkillinen allerginen reaktio ovat erilaisia uhkia kuin ylipaino ja sen mahdollisesti aiheuttamat sairaudet vuosien kuluttua. Luottamus ruoan turvallisuuteen voi olla kuluttajille hyvin monitulkintainen asia.

Kysymys kuuluukin: mitä turvallisuudella lopulta tarkoitetaan? Turvallisuuteen liittyy kiinteästi riskin käsite, jonka kautta turvallisuutta on mahdollista tarkastella. Riskejä on erilaisia, eivätkä asiantuntijoidenkaan käyttämät luokitukset riskeistä ole yhtenäisiä. Näyttää kuitenkin siltä, että nyt kuluttajatkin alkavat huolestua kansanterveydellisistä riskeistä, kun aikaisemmin kuluttajien huoli on kohdistunut lähinnä kemiallisiin ja mikrobiologisiin riskeihin (esim. lisäaineet, salmonella). Kuluttajille voi kuitenkin olla eri asia syödä perunalastuja, jos heitä mahdollisesti uhkaa tulevaisuudessa ylipaino, korkea verenpaine tai diabetes, eli riski jonka he ottavat tietoisesti, kuin jos perunalastuissa osoitetaan olevan syöpävaarallista akryyliamidia, josta kuluttajat eivät ole aikaisemmin kuulleetkaan. Vapaaehtoisuus on tärkeä riskin määrittäjä kuluttajille, vaikka asiantuntijoiden laskelmat riskien todennäköisyydestä painottaisivatkin riskejä toisin. 
Luottamuksen eri ulottuvuudet muodostavat kokonaisuuden, joka kuvastaa laajemminkin perusluottamusta maailmaan ja turvallisuuden kokemusta (ks. Giddens 1991). Ruokaan kohdistuva luottamus ei ole irrallaan yhteiskunnasta vaan osa henkilökohtaista, mutta sosiaalisissa ja kulttuurisissa puitteissa rakentuvaa, suhdetta maailmaan. Luottamus näyttää kasautuvan. Ne, jotka luottavat ruokaan yleisellä tasolla, luottavat muita enemmän myös yksittäisiin elintarvikkeisiin, eri toimijoihin ja muihin ihmisiin.

Tuloksemme kertovat elintarvikkeisiin ja ruokaan kohdistuvan luottamuksen moniulotteisuudesta. Vaikka tutkimus ei pureutunut kovin syvälle kuluttajien luottamuksen vaihteluun esimerkiksi valmistajien tai kauppojen välillä, tuoteryhmän sisällä tai erilaisissa ruokaskandaaleissa tai -kriiseissä, osoittavat tulokset luottamuksen kontekstisidonnaisuuden. Luottamus vaihtelee tuotteittain, toimijoittain ja tilanteittain. Kriisin kohdatessa monet tekijät vaikuttavat kuluttajien tulkintaan siitä, mistä se on aiheutunut sekä kenen ja millä tavoin se tulisi korjata. Kriisitilanteessa luottamus voidaan menettää, eikä sen palauttaminen ole helppoa. Luottamus kuitenkin punnitaan varsinaisesti vasta ongelmien ilmetessä. Esimerkiksi Isossa-Britanniassa viranomaisten lepsu suhtautuminen BSE-kriisiin sen alkuvaiheissa murensi kuluttajien luottamusta viranomaisiin. Vastaavasti Suomessa viranomaisten määrätietoinen ote BSE:hen ilmeisesti hillitsi voimakkaiden reaktioiden syntymistä silloin, kun ensimmäinen ja toistaiseksi ainoa hullun lehmän taudista kärsivä nauta vuonna 2001 löytyi. Tässä mielessä suomalaisten suhteellisen vankka luottamus ruokaan ei ole mitenkään yllättävää, sillä Suomessa pahasti luottamusta horjuttaneita kriisejä on ollut melko vähän. Sen sijaan olisi syytä huolestua, jos näinkin vakaissa oloissa kuluttajat olisivat ruoan suhteen erityisen epäluottavaisia.

\section{Kirjallisuus}

Berg, L. 2000. Tillit til mat i kugalskapens tid. Statens institutt for forbruksforskning. Rapport nr. 5 - 2001. Lysaker.

Berg, L. \& Kjærnes, U. 2001. Consumers and food safety policies in the Nordic countries. Teoksessa Kjærnes, U. (toim.). Eating patterns: A day in the lives of Nordic peoples. SIFO Report No. 7 - 2001. SIFO. Lysaker. $235-254$.

Giddens, A. 1991. Modernity and self identity: self and society in the late modern age. Stanford University Press. Stanford, California.

Gronow, J. 1998. "In food we do not trust”. Kulutuksen vaarat ja riskit. Tiede ja Edistys 23, 1: 1-10.

Ilmonen, K. (toim.). 2000. Sosiaalinen pääoma ja luottamus. SoPhi. Jyväskylä.

Ilmonen, K. \& Jokinen, K. 2002. Luottamus modernissa maailmassa. SoPhi. Jyväskylä.

Järvelä, K. 1998. Kuluttajien mielipiteet elintarvikkeisiin liittyvistä terveysvaaroista ja elintarvikevalvonnasta. Elintarvikeviraston tutkimuksia 1. Helsinki.

Miles, S., Brennan, M., Kuznesof, S., Ness, M., Ritson, C. \& Frewer, L. J. 2004. Public worry about specific food safety issues. British Food Journal 106, 1: 9-22.

Misztal, B. A. 1996. Trust in modern societies. Polity Press. Cambridge, UK.

Niva, M., Piiroinen, S. \& Mäkelä, J. 2005. Natural or designed healthfulness? Consumer understandings of fruit and veg as functional foods. Teoksessa Pitkäkoski, T., Pajuniemi, S. \& Vuorenmaa, H. (toim.). Food Choices and Healthy Eating Focusing on Vegetables, Fruits and Berries. Seinäjoki Polytechnic Publications B. Research Reports 22.

Piiroinen S., Mäkelä J. \& Niva M. 2004. Luottavaiset suomalaiset? Kuluttajien näkemykset ruoan turvallisuudesta. Kuluttajatutkimuskeskuksen julkaisuja 4/2004.

Poppe C. \& Kjærnes U. 2003. Trust in Food in Europe. A Comparative Analysis. Professional Report No. 5. National Institute for Consumer Research, Oslo. http://www.trustinfood.org/SEARCH/BASIS/tif0/all/wp/DDD/24.pdf 